\title{
Ano Internacional da Tabela Periódica 2019 A Química Festeja a Juventude
}

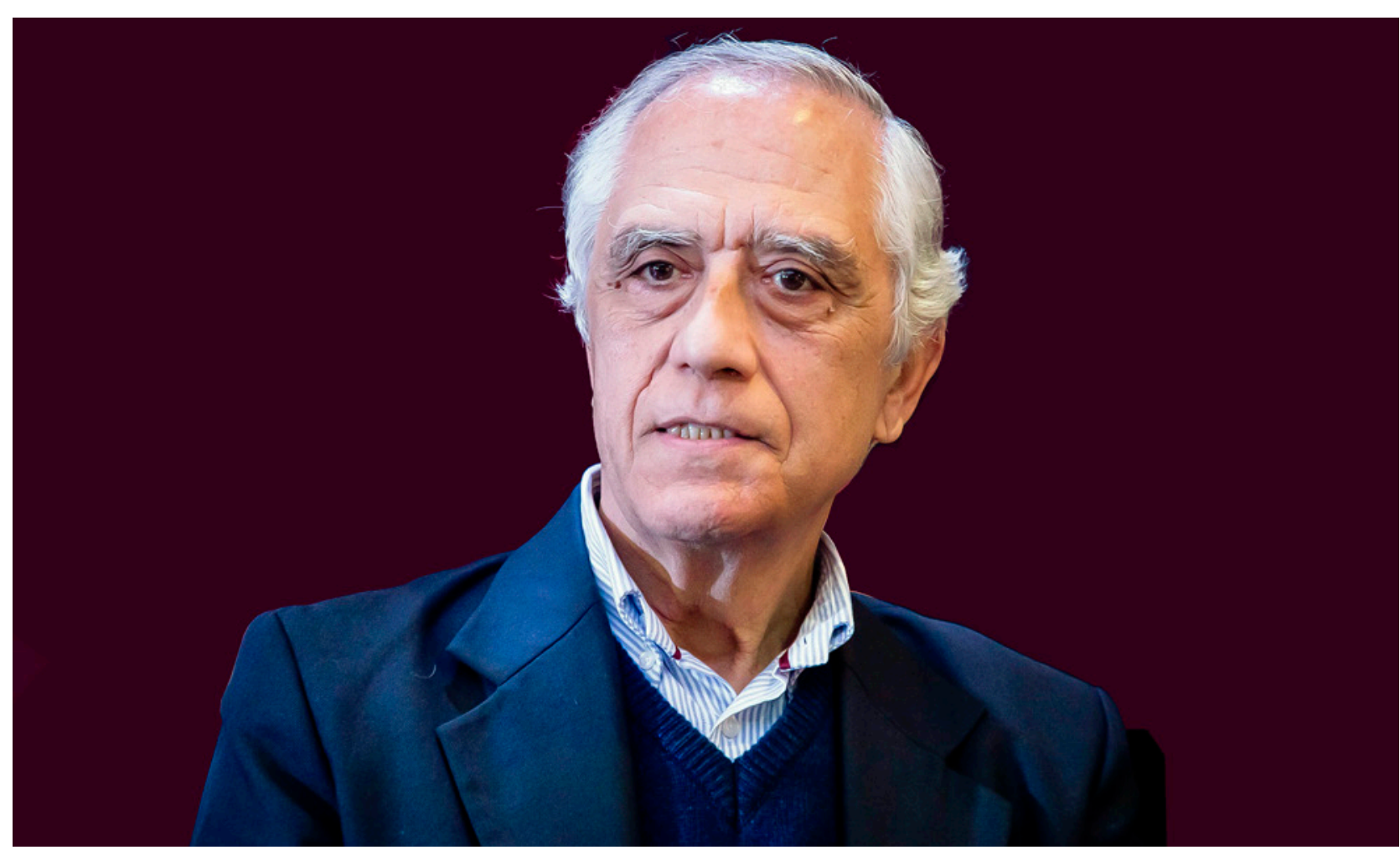

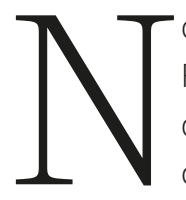

os 150 anos de celebração da Tabela Periódica, temos um belo edifício onde alojar os 118 elementos conhecidos, 94 deles naturais (ainda que apenas em vestígio nalguns casos) e 24 totalmente artificiais e de vida muito efémera. Tabela fechada! Outros surgirão para quebrar a beleza da Tabela atual. Para a Química, alguns dos atuais já parecem inatingíveis ou, talvez, inúteis, mas o inútil poderá vir encontrar utilidade. Assim tem acontecido repetidamente na história da ciência.

Valeu a pena celebrar a odisseia desta construção. Celebramos o passado com os olhos postos no futuro e na juventude que se propõe encontrar e desafiar novos problemas. Se no Congresso de Karlsruhe (1860) Portugal teve apenas um representante, hoje temos representação nos espaços mais recônditos da Química e podemos esperar uma afirmação ainda mais forte no futuro próximo. É por este futuro que trabalhámos em 2019. É esta Química jovem que hoje construímos e celebramos.

Não terminara ainda o Ano Internacional da Tabela Periódica e já surgía uma ameaça que se limitava a usar uns 4 elementos para, em poucas semanas, fechar em casa mais de um terço da
José Ferreira Gome Professor Catedrático da Universidade do Porto

Ex-Secretário de Estado do Ensino Superior

Comissário Nacional para as Comemorações do Ano Internacional da Tabela

Periódica 2019 
humanidade e parar a economia de forma só imaginada em pesadelos ficcionados. Para que servem afinal todos os outros 114 que celebramos? Não estaremos a regressar aos quatro elementos da antiguidade, dispensando toda a outra Química, mesmo a dos 94 que foram sendo encontrados na natureza, antes e depois de Mendeleiev?

Vivemos um exercício de guerra biológica (originada intencionalmente ou não) para que manifestamente nenhuma potência militar ou pacifista estava preparada. 0 exercício vai certamente aprofundar a reflexão sobre o posicionamento estratégico dos blocos políticos e comerciais em que a humanidade se organiza. Poderemos vir a assistir a uma marcha atrás na desindustrialização da Europa e, consequentemente, a uma revalorização da Química nesta velha Europa.

Mantemos a Química temporariamente em teletrabalho, mas mantemos a esperança firme de que possamos regressar a breve prazo aos nossos laboratórios para reencontrar lá toda a Química que amamos. Saindo do confinamento, vai-nos ser permitido abraçar os amores antigos, sem desperdiçar toda a reflexão destas semanas ou meses.

A besta que nos ataca poderá usar apenas 4 elementos, mas socorre-se traiçoeiramente de outros para fazer o seu caminho. Marca encontro sinistro dentro das nossas células e aproveita-se desse acolhimento inocente para pôr a maquinaria do hospedeiro ao seu serviço. Encontra ali os outros elementos essenciais aos processos biológicos que lhe permitem andar por aí. Do lado da Ciência, estamos em todo o mundo a lançar mão de todos os recursos e de todos os elementos para atenuar o impacto, combatendo-o dentro de cada célula, mas também no exterior. Uma simples lavagem com água e sabão, ou outro detergente que a Química foi sintetizando ao longo do último século, permite "matar" o vírus ao destruir a sua vestimenta externa. Enquanto não dispomos de uma terapia adequada nem beneficiamos de algum mecanismo de imunização, vivemos com a receita simples de que lavar-se e ficar recolhido é a melhor solução para oferecer tempo aos que se mantêm ativos nos seus laboratórios e nos hão de salvar. Assim esperamos! Ou que a besta desista...
Este retiro de 2020 permite-nos avaliar meIhor e mais profundamente os prazeres dos bons velhos tempos. Como invejamos o 2019, quando podíamos sair e saudar os amigos efusivamente, de longe e de perto, velhos e novos. Que saudades do 29 de janeiro cheio de notícias de jovens a celebrar a Química nas nossas praças e avenidas, a apresentar ao público as suas Tabelas Periódicas humanas. Ninguém sabia de uma imensa metrópole chamada Wuhan onde se podiam comprar algumas carnes estranhas num mercado movimentado. Que belo o dia 12 de fevereiro com as mulheres investigadoras químicas de todo o mundo a discutir os seus sucessos sem se perguntarem pela chegada do vírus à Europa nem se forçarem ainda em teletrabalho. Que melhor celebração da primavera senão a plantação de uma floresta em memória dos elementos da Tabela Periódica sem querer saber da chegada do vírus a Portugal e das últimas medidas de isolamento. Só as árvores ficaram isoladas no alto da serra ou no pátio da escola à espera de alguma água que as mantivesse vivas e do sol que as faria crescer. Em abril, celebrámos os metais com música e alegria certa, em espaço aberto ou em sala confinada, mas sem receio de expressar esperança no futuro livre de constrições. E o 2019 continuou alegre e celebrativo na confiança. Celebramos o sol e o mar para logo de seguida celebrar a chegada dos novos elementos, sempre jovens e acalentando os seus sonhos adolescentes. Levamos a Química ao teatro com total adesão de grandes e pequenos à Tabela Periódica. Reunimos em Grande Encontro, fechamos com a exposição da iniciativa artística de alunos, professores e investigadores.

A Sociedade Portuguesa de Química tomou a iniciativa e apoiou, mas a Química em Portugal tomou a iniciativa nas suas mãos, assumiu a festa como sua e encheu salas de aula e laboratórios, envolveu jovens alunos e investigadores seniores. Todos fizeram a sua festa! Todos merecem uma palavra de parabéns e de certeza quanto ao futuro.

\section{José Ferreira Gomes}

QUímiCA | Vol. 43 | N.0 155 | 2019 | 227 